\title{
Pedro Lemebel: revelación y rebelión en sus crónicas desde el margen
}

\section{Fernando Checa-Montúfar ${ }^{1}$}

Recibido: 2015-04-14

Enviado a pares: 2015-04-15
Aprobado por pares: 2015-06-11

Aceptado: 2015-06-18

DOI: 10.5294/pacla.2016.19.1.7

Para citar este artículo / To reference this article / Para citar este artigo

Checa-Montúfar, F. (Marzo de 2016). Pedro Lemebel: revelación y rebelión en sus crónicas desde el margen. Palabra Clave, 19(1), 156-184. DOI: 10.5294/pacla.2016.19.1.7

\section{Resumen}

La crónica ha surgido en América Latina como un espacio ideal para la voz de los excluidos — de esos que no cuentan mucho para el periodismo tradicional-, para contar lo que parece que no sucede, para dar cuenta de ello en su maravillosa "banalidad". Ahí está su fuerza política sobre todo cuando quien narra es testigo y protagonista - ya no informante sino sujeto de la enunciación - de una historia que revela y se rebela: revela el lado oscuro de la sociedad a través de una etnografía de la vida cotidiana de los homosexuales marginales chilenos y su drama en una sociedad patriarcal e injusta contra la cual su escritura barroca se rebela. Este trabajo analiza las crónicas de Pedro Lemebel publicadas en Loco afán. Crónicas de sidario (2000) como una muestra de escritura contrahegemónica que cuestiona la colonialidad y la biopolítica del poder en una sociedad desigual, racista, patriarcal, homofóbica, disciplinaria, como la del Chile en la época de Pinochet, y luego ya recuperada la democracia.

1 Universidad Politécnica Salesiana, sede Quito, Ecuador. ferchemon@gmail.com 


\section{Palabras clave}

Crónica, subalternidad, biopolítica, geopolítica del conocimiento, sobrecargas representativas, periodismo, cronistas chilenos (Fuente: Tesauro de la Unesco).

\section{Peter Lemebel: Revelation and Rebellion in his Chronicles from the Sidelines}

\section{Abstract}

Chronic has emerged in Latin America as an ideal space for the voice of the excluded- for those who do not have much of traditional journalism, a space to tell what seems not to be happening, to account for it in his wonderful "banality". There's your political force especially when you witness who narrates and who stars- but no longer an informant subject to enunciation- a story that reveals and rebels: it reveals the dark side of society through an ethnography of everyday life of marginalized gay Chileans and drama in a patriarchal society and unjust against which the baroque writing rebels. This paper analyzes the chronicles of Pedro Lemebel published in Loco afán. Crónicas de sidario (2000) as a counter-writing sample that questions coloniality and biopolitics of power in an unequal, racist, patriarchal, homophobic society, discipline, such as Chile in the Pinochet era, and then democracy was recovered.

\section{Keywords}

Chronic, subordination, biopolitics, geopolitics of knowledge, representative overload, journalism, Chilean chroniclers (Source: Unesco Thesaurus). 


\section{Pedro Lemebel: revelação e rebelião em suas crônicas a partir da margem}

\section{Resumo}

A crônica surgiu na América Latina como um espaço ideal para a voz dos excluídos - desses que não são tão considerados para o jornalismo tradicional-, para contar o que parece que não acontece, para dar conta disso em sua maravilhosa "banalidade". Nisso se encontra sua força política, especialmente quando quem narra é testemunha e protagonista — já não informante, mas sim sujeito da enunciação - de uma história que revela e se rebela: revela o lado escuro da sociedade por meio de uma etnografia da vida cotidiana dos homossexuais marginais chilenos e seu drama numa sociedade patriarcal e injusta contra a qual sua escrita barroca se rebela. Este trabalho analisa as crônicas de Pedro Lemebel publicadas em Loco afán. Crónicas de sidario (2000), como uma amostra de escrita contra-hegemônica que questiona a colonialidade e a biopolítica do poder numa sociedade desigual, racista, patriarcal, homofóbica, disciplinar, como a do Chile na época de Pinochet, e depois de recuperada a democracia.

\section{Palavras-chave}

Crônica, subalternidade, biopolítica, geopolítica do conhecimento, sobrecargas representativas, jornalismo, cronistas chilenos (Fonte: Tesauro da Unesco). 
Felices los normales, esos seres extraños. Los que no tuvieron una madre loca, un padre borracho, un hijo delincuente, una casa en ninguna parte, una enfermedad desconocida, los que no han sido calcinados por un amor devorante...

Roberto Fernández Retamar

No soy Pasolini pidiendo explicaciones

No soy Ginsberg expulsado de Cuba No soy un marica disfrazado de poeta

No necesito disfraz

Aquí está mi cara Hablo por mi diferencia

Defiendo lo que soy

$Y$ no soy tan raro

Me apesta la injusticia

Y sospecho de esta cueca democrática...

Pedro Lemebel

De vieja historia, pues viene de las crónicas de Indias y de viajes con las que Europa fue imaginando y configurando al “otro", la crónica es un género híbrido, fronterizo entre periodismo y literatura, es el "ornitorrinco de la prosa” (Villoro, 2012): combina elementos y recursos de la novela, reportaje, cuento, entrevista, teatro, ensayo y autobiografía (de esto magnífico exponente es Lemebel); pero debe mantener su identidad: "usado en exceso cualquiera de estos recursos resulta letal. La crónica es un animal cuyo equilibrio biológico depende de no ser como los siete animales distintos que podría ser" (p. 579).

Como expresión del periodismo contemporáneo, sus orígenes se remontan a fines del siglo XIX en América Latina con figuras como José Martí, Rubén Darío, Gómez Carrillo, Julián del Casal ... (González, 1983; Ramos, 1989; Rotker, 1992). Según Julio Ramos, "la crónica surge como una vitrina de la vida moderna” (p. 90) y, dado que empezó a difundirse a través del periódico, fue liquidando el aura y la exclusividad del escritor, para dar paso al cronista y al reportero. ${ }^{2}$ En las últimas décadas, este género ha ido

2 Un desarrollo sintético de este proceso originario latinoamericano (la "crónica es un género bien sudaca" ha dicho Caparrós, 2007, p. 8), varias décadas antes del New Journalism de la década de 1960 en los Estados Unidos, al que se le suele atribuir la paternidad del género, puede consultarse Checa (2014). 
adquiriendo una importancia cada vez mayor por sus posibilidades expresivas: ahí está el espacio que ha logrado en revistas impresas y digitales y en la industria editorial que ha visto en la producción cronística latinoamericana una suerte de nuevo boom, ${ }^{3}$ pero ahora periodístico-literario; revistas como Gatopardo, Etiqueta Negra, El Malpensante, Soho, Marcapasos, Orsái, Pie Izquierdo, etc., y varias antologías publicadas por diversas editoriales (FCE, 2006; Silva y Molano, 2006; Osorno, 2009; Jaramillo, 2012; Carrión, 2012; Fonseca y El Khadi, 2012, Yánez, 2014).

Característica fundamental: la crónica es un género rebelde no solo por su carga de subjetividad (alguien que cuenta desde su mirada) contradictora de la exigencia de "objetividad" del periodismo tradicional, sino sobre todo porque este tipo de periodismo se ocupa casi siempre de los personajes de la vida pública, de los grandes acontecimientos; mientras la crónica se rebela contra eso:

[...] en sus mejores casos, una crónica busca no solo a personajes públicos - autoridades, celebridades, expertos-: busca sobre todo a personas extraordinarias en su anonimato, esos extras de cine mudo a quienes nadie les ha pedido la palabra [...] tiene el privilegio de contar no solo lo que sucede, sino sobre todo lo que parece que no sucede [...] vuelve extraordinario lo más banal (Villanueva, 2012, pp. 589, 590).

O para ponerlo en palabras de Caparrós (2007), la crónica sirve "para contar las historias que nos enseñaron a no considerar noticia $[. .$.$] La in-$ formación' busca lo extraordinario; la crónica, muchas veces, el interés de la cotidianidad. Digo: la maravilla en la banalidad” (p.9). Es decir, para visibilizar a los invisibles, pero atractivamente. Se busca, sobre todo, que el lector no se aburra (en especial en esta época de pantallas múltiples donde la "monótona" letra tiene duras y más lúdicas competencias), pero también "entretener" con estilos y temas que no han tenido cabida en el periodismo tradicional que "consiste en decirle a muchísima gente qué le pasa a muy poca: la que tiene poder” (p. 10). Así, la crónica contemporánea democratiza el

3 Jon Lee Anderson, en un homenaje a García Márquez en Bogotá en marzo de 2014, afirmó que este boom comenzó a fraguarse a finales del siglo XX "cuando una generación de chicos salían a la calle con nuevas inquietudes a contar un nuevo mundo [y debido a que] los latinos son cuentistas natos, sociedades muy orales, llenas de gente que quiere contar historias" (Rebollo, 2014). 
referente periodístico al dar escenario y protagonismo a los que no contaban, no eran dignos de una historia mediática.

Además, la crónica es documento social para la denuncia y la reflexión, pues, dada su flexibilidad y carencia de límites, y el atractivo de su hibridez escritural, puede contar lo que otros géneros no pueden. No extraña, entonces, que una organización de las Naciones Unidas haya visto en ella, y en uno de sus más brillantes exponentes contemporáneos, Martín Caparrós, el vehículo ideal para revelar al mundo, más allá del informe oficial y las estadísticas, el drama de la migración (2009, escrito bajo contrato entre Caparrós y esa organización), o por iniciativa propia que ese cronista haya dedicado cinco años a recorrer el mundo para trazar el mapa del hambre (2015) "la metáfora más violenta de la desigualdad".

Medio ideal para la denuncia porque hace rato la crónica ha venido fisurando las narraciones "legítimas" y convirtiéndose en un

[...] incómodo testigo de aquello que no debiera verse, por doloroso
o por ridículo, que a veces es lo mismo [...] La crónica se re-coloca
hoy frente al logos pretendido de la modernidad como discurso com-
prensivo, al oponérsele a este, otra racionalidad, en tanto ella puede
hacerse cargo de la inestabilidad de las disciplinas, de los géneros,
de las fronteras que delimitan el discurso (Reguillo, 2000, pp. 61-62).

Según lo hemos señalado en otra oportunidad (Checa, 2003), para muchos periodistas y escritores latinoamericanos la crónica ofrece la insoslayable oportunidad de retratar a las sociedades como ellas son, iluminar una realidad desmesurada que asume el reto de inventar recursos (por eso nuestras exuberantes expresiones melodramáticas, nuestro "realismo mágico", lo "real maravilloso", etc.) para "hacer creíble nuestra vida". Así, la crónica es el registro de una realidad grandilocuente que supera la ficción.

En este sentido, en América Latina, la crónica ha surgido como un espacio ideal para la voz de los excluidos y como una caja de resonancia

4 Como lo reconoció García Márquez al recibir el Premio Nobel: "Las criaturas de esta realidad desaforada hemos tenido que pedirle muy poco a la imaginación, porque el desafío mayor ha sido la insuficiencia de recursos para hacer creíble nuestra vida". Concepto coincidente con lo "real maravilloso" de Alejo Carpentier que resalta el esplendor de un referente al que deben corresponder recursos escriturales renovados. 
masiva de los reclamos de la marginalidad. En especial cuando quien narra es testigo y protagonista - ya no informante sino sujeto de la enunciación- de una historia que revela y se rebela. En esta perspectiva se ubica la obra de Pedro Lemebel ${ }^{5}$ (vencido por el cáncer en enero de 2015). Acto de revelación porque rompe el silenciamiento de los dominados, que ahora ya no tienen que atenerse a la lógica discursiva dominante o del periodista ventrílocuo, y porque genera polifonía y visibiliza alteridades: ya no son las "fuentes oficiales" las que cuentan y protagonizan las historias, son "otras" las fuentes que se visibilizan y adquieren legitimidad por vía del periodismo literatura. Y acto de rebelión por la función desmitificadora y de denuncia que cumple esta narrativa, cuyos referentes develan una geografía urbana oculta, secreta, sus ritos y retos a una sociedad patriarcal que ve como nefandos y detestables a los homosexuales, a las "locas"; y porque visibiliza los pensares y sentires de los seres proscritos, marginales, ilegítimos, de los "otros"; es la rebelión de un género narrativo, impugnador y desacralizador, que revela públicamente el "trasfondo escénico”, el backstage (Goffman, 1981), lo "obsceno" de nuestras sociedades, ese lugar ubicado en las regiones posteriores y que debe quedar oculto para que la "máscara" de la representación social hegemónica quede intacta, pulcra. En la obra de Lemebel, encontramos un discurso crítico sobre la vida cotidiana chilena, en especial la del mundo marginal de la homosexualidad, en la brutal dictadura de Pinochet. Una "mirada incómoda" (Morales, 2009) de un momento dramático de su historia, una mirada incómoda al backstage de una sociedad que se pretendía ejemplar para América Latina: el "modelo chileno".

En suma, la obra de Lemebel cuestiona dos dimensiones clave del poder contemporáneo. La primera es la biopolítica. Según Foucault (1994), a finales del siglo XVIII empieza a constituirse una "modernidad biológica”; es decir, un biopoder y una biopolítica que tendría como consecuencia el surgimiento de mecanismos de clasificación social, disciplinamiento y control: por un lado, la "proliferación de tecnologías políticas que

5 Obra que últimamente ha sido analizada desde múltiples perspectivas (Morales, 2009; Blanco y Poblete, 2010; López, 2011; Marconi, 2012; Rossi, 2013; Moure, 2014; Poblete, 2014; Sabo, 2014). O desde la perspectiva de lo queer (Maristany, 2008; Arboleda, 2011), denominación polémica empezando por el origen anglosajón de la palabra que además remite a homosexuales blancos; algunos de ellos discriminaron a Lemebel por ser "indiecita", en el bar Stonewell de Nueva York (Lemebel, 2000, pp. 70, 71). 
a partir de allí van a invadir el cuerpo, la salud, las maneras de alimentarse y alojarse, las condiciones de vida, el espacio entero de la existencia” (p. 174); y por otra parte, el surgimiento de "una sociedad normalizadora", de un poder disciplinario destinado a "enderezar las conductas ... Es un poder modesto, suspicaz, que funciona según el modelo de una economía calculada pero permanente" y que utiliza "humildes procedimientos" traducidos en tres instrumentos simples: la inspección o vigilancia jerárquica, la sanción normalizadora y el examen (pp. 175 y ss.). La biopolítica ubica a cada individuo en un lugar determinado para poder controlarlo.

La segunda es la geopolítica de conocimiento (Mignolo, 2003) que privilegia y valora el conocimiento occidental metropolitano logocéntrico, ese "universal universalizante" (Wallerstein) legitimado por una colonialidad del poder que rechaza o subvalora a aquel conocimiento que no corresponde a sus parámetros epistemológicos y que tiene formas de saber y conocer con distintas lógicas y dinámicas culturales estructuradas en culturas populares configuradas por el cruce de lo tradicional y lo moderno, lo histórico y lo nuevo, lo masivo y lo popular; que rechaza a ese conocimiento muy imbricado con la cotidianidad y los usos concretos, inmediatos y poiéticos (De Certeau, 1996) que de él pueden darse. Esa colonialidad del poder también impide ver a quienes producen ese conocimiento alternativo como agentes legítimos; solo los ve como "informales" del mercado cultural. Así, la geopolítica de conocimiento construye jerarquías y establece una subalternización geocultural, política, racial, etc.; al legitimar y validar solo los primeros componentes de una serie de dicotomías con las que la modernidad prestigia unos saberes/sujetos, mientras rechaza otros: logos frente a rito, culto frente a popular, moderno frente a tradicional, saber científico frente a saber mítico, civilización frente a barbarie, moral frente a inmoral, legítimo frente a ilegítimo, normal frente a anormal, etc.

Este trabajo analiza las crónicas de Pedro Lemebel publicadas en Loco afán. Crónicas de sidario (2000), esa barroca "etnografía sobre el dolor marica” (González Cangas, 2007), como una muestra de escritura contrahegemónica que, entre otras virtudes, cuestiona la geopolítica del conocimiento (Mignolo, 2003) y la biopolítica (Foucault, 1994) de una sociedad desigual, 
racista, patriarcal, homofóbica, disciplinaria, como la de Chile en la época de Pinochet... y, luego, cuando inició "la cueca democrática".

\section{Lemebel: revelación y rebelión}

Efectivamente, Pedro Lemebel es el testigo protagonista que revela y se rebela con sus crónicas, es el "freak contrahegemónico" (Monsiváis, 2001). Traslada a la "esfera pública" una realidad antigua con una luz nueva, incisiva, impugnadora y desde una condición extremadamente marginal, la homosexualidad: soy "maricón y pobre, mis dos títulos nobiliarios ... [además] de indio y mal vestido", dice, y al hacerlo, pone en evidencia esa triple marginalidad de género, clase y raza — con el agravante de corresponder a un género "anormal" - con la que la biopolítica y la colonialidad de poder en nuestras sociedades marca e infama a los seres ubicados al margen de la marginalidad. Pero, no obstante o por esa condición, son seres social, política y culturalmente vivos. La obra de Lemebel es un magnífico registro revelador y rebelde de esa condición.

La perspectiva ideológica lemebeliana tomó cuerpo en el trabajo plástico colectivo desarrollado en las Yeguas del Apocalipsis, colectivo de arte formado con Francisco Casas (1987), cuyas representaciones nomádicas entre la performance, la fotografía, el video, el mimo, la parodia, el circo, el happening, el desfile de modas, la farsa, según el propio Lemebel, "remiten a la institución del arte a la frivolidad burlesca de la cinematografía comercial” (Lemebel, citado en Richard, 1994, p. 71); pero se corporizó, fundamentalmente, en el acto escritural que le ha permitido una masiva difusión. Además de artículos publicados en revistas y periódicos nacionales y extranjeros, su obra cronística, verdadero "discurso de la historia" reciente de Chile (Moure, 2014), es la siguiente: La esquina es mi corazón (1995); Loco afán. Crónicas de Sidario (1996); De perlas y cicatrices (1998); Zanjón de la Aguada (2003); Adiós mariquita linda (2004); Serenata cafiola (2008), y Háblame de amores (2012). También ha publicado dos libros de ficción: Incontables (relatos, 1986) y Tengo miedo torero (novela, 2001). Además, Josefina Alemparte, su editora de Planeta, ha anunciado la próxima publicación de $M i$ amiga Gladys, recopilación de textos sobre la dirigente comunista Gladys Marín, y la que será su segunda novela: El éxtasis de delinquir. 
Así, dos ejes de género que atraviesan su obra. El primero, la crónica, incluso esto es válido para su novela Tengo miedo torero, que en realidad es una crónica novelada del amor entre un militante del Frente Patriótico, Manuel Rodríguez, y un homosexual que lo apoya, "sin saber sabiendo", en sus planes políticos en 1986, año del frustrado atentado a Pinochet. El segundo eje es la revelación del complejo mundo de la identidad homosexual con el cual se rebela al exponer un mundo prácticamente inédito en la narrativa chilena.

Este predominio de la crónica como género no es raro en su perspectiva ideológica y proyecto sobre (desde) el margen de la marginación social. Dado el referente - la homosexualidad como leit motiv de toda su obra- Lemebel ve la necesidad de hacerlo a través de un discurso "otro" que no cabe en los géneros auratizados de la literatura (insistamos, su último libro es una "crónica novelada"), de ahí que recurre a un "género híbrido", adecuado a su "escritura en tanto ella [la crónica] es una estrategia de micropolítica $[\ldots][$ de] devenires minoritarios $[\ldots]$ crónica porque tiene que ver con algo de biografía, con algo de narrativa, con una poética como coraza escritural frente a los poderes de la literatura" (citado en Plaza, 1999, p. 123). Más que "estrategia de micropolítica", la crónica lemebeliana es doblemente política: si para Caparrós (2006), al transgredir la ideología del periodismo que considera noticia lo que le pasa a la gente "importante", la que tiene poder, la crónica es política (p. 10), mucho más lo será cuando da cuenta del drama de la subalternidad.

Doble rebelión de género, entonces, no solo frente a la sociedad logo-falo-céntrica, sino también ante un canon literario anquilosado en registros incompatibles con la emergencia de sujetos más cercanos a la estética de los medios de comunicación que a la letrada. Tómese en cuenta que las crónicas de Lemebel empiezan por ser publicadas en revistas y periódicos, más masivos que el libro; incluso sus "crónicas radiales" (De perlas...) fueron escritas originalmente para ser difundidas en su programa Cancionero, de Radio Tierra, desde 1996. Más aún, esa perspectiva ideológica y proyecto reivindicativo han tenido un soporte audiovisual, aunque no tan masivo pero sí importante, en sus trabajos plásticos con las Yeguas... 
En su condición de testigo protagonista, triple marginal que testimonia, que habla, Lemebel representa a la "literatura iletrada" a la que se refiere Manuel Zapata Olivella (1997), aquella que ha sedimentado la tradición oral de nuestros pueblos — su oralitura-, ya que

\begin{abstract}
[...] el carácter fundamental del discurso poético o narrativo no lo constituye el alfabeto, sino el pensamiento y el lenguaje articulado. En consecuencia, el fenómeno llamado "literatura" es el resultado de la creación colectiva de analfabetos y letrados; de adultos y niños; de varones y mujeres; de sabios y profanos (p. 19).
\end{abstract}

Y la representa, pues Lemebel historiza, registra, narra, reflexiona y da visibilidad (a través de la representación ${ }^{6}$ ) al mundo homosexual santiaguino, pero partiendo de su cultura, de su experiencia, de sus formas de ser, pensar y sentir. Para ello escoge la crónica, escrita y radial, "como coraza escritural frente a los poderes de la literatura" y adecuada para recrear la epicidad cotidiana con la que el marginal sobrevive en una sociedad excluyente, más aún en una que lo expulsa por partida triple. Su referente no es el "otro" al que mira desde la distancia del letrado (llámese antropólogo, periodista, escritor, etc.); es él mismo y sus pares, con el propósito de plantear reivindicaciones y lograr legitimidad desde la diferencia, lo cual es absolutamente claro en la frase epigráfica de este trabajo: "Hablo por mi diferencia / Defiendo lo que soy”.

En el marco de lo expuesto, las crónicas de Loco afán..., esa barroca "etnografía sobre el dolor marica" (González Cangas, 2007), son un buen objeto de análisis para continuar articulando algunas reflexiones sobre esa perspectiva y proyecto lemebeliano. Estas crónicas recorren diversas historias personales y colectivas de la homosexualidad chilena, narra e historiza las múltiples aristas de la exclusión y del estigma que sufre en el Chile que va desde la época de Allende hasta la de la "cueca democrática", pasando por la noche oscura de la dictadura. Es un tiempo histórico que ve surgir, a mediados de la década de 1980, la "mano cadavérica" de la "sombra", el "bicho", el "misterio", la "polla gol”, la "lotería”; es decir, el sida que "llegó como una

6 Representación en el doble sentido: recrea una realidad, la homosexualidad santiaguina, y expresa a nombre de una colectividad sus pensares y sentires, su mundo. 
nueva forma de colonización por el contagio. Reemplazó nuestras plumas por jeringas, y el sol por la gota congelada de la luna en el sidario" (Lemebel, 2000, p. 9; en adelante, las citas que correspondan a esta obra tendrán, al final de cada una de ellas, únicamente el número de página entre paréntesis). Y que le sirve a Lemebel como metáfora de la dictadura (Rossi, 2013).

Esas crónicas constituyen una narrativa erótica y que erotiza, típica en toda la obra del autor; más aún, que homosexualiza la realidad citadina, que busca sacar a la luz una realidad vergonzante (para algunos) y que, como se señaló, va en contra del orden patriarcal de la modernidad y lo interpela, subvierte y desacraliza a través no solo de exponer ese mundo, que muchos quisieran mantenerlo oculto, sino también de un estilo irónico, delirante, paródico, sarcástico, audaz, pero no carente de compasión, humor, remitencias lingüísticas populares, intensidad ... ternura: "¿Tiene miedo que se homosexualice la vida? / Y no hablo de meterlo y sacarlo / Y sacarlo y meterlo solamente / Hablo de ternura compañero / Usted no sabe / Cómo cuesta encontrar el amor / En estas condiciones" (p. 95). Y todo ello con una compleja y polisémica prosa poética.

Son crónicas sobre una marginalidad viva que, no obstante sus dramas, articulan solidaridades, estrategias de supervivencia, posiciones y acciones políticas no solo contra la dictadura y una sociedad tan injusta como hipócrita que la democracia no curó, sino también contra una biopolítica del poder que penetra en los cuerpos, los comportamientos y los saberes hasta de los seres más marginales, tratando de "higienizar" y normar la vida, pero no siempre con éxito. Y todo ello en una ciudad homosexualizada, de una geografía homoerótica urbana que expulsa y convoca, plagada de tentaciones para el fugaz y posmortificante encuentro en un "no lugar" que atrae intermitentemente a los seres "normales":

De escrituras urbanas y grafías corpóreas que en su agitado desplazamiento discurren sus manuscritos. La ciudad testifica estos recorridos en el apunte peatonal que altera las rutas con la pulsión dionisiaca del desvío. La ciudad redobla su imaginario civil en el culebreo alocado que hurga en los rincones del deseo proscrito. La ciudad estática se duplica móvil en la voltereta cola del rito paseante que al homosexual aventurero convoca (p. 87). 


\section{Los "no lugares" de la ciudad moderna}

El vértigo de la modernidad tiene una de sus expresiones más alucinantes en la ciudad contemporánea caracterizada por la desmesura de su crecimiento poblacional, incontenibles flujos migratorios, proliferación de barrios marginales, hacinamiento, incremento exponencial de la violencia y de los índices de inseguridad, la contaminación, un tráfico vehicular caótico. ${ }^{7}$ Estos son los factores que están produciendo procesos de descentralización, desurbanización y desterritorialización (Martín-Barbero, 2002), pues la vida citadina es cada vez más fragmentaria y vivida en el vértigo de un fluir incesante, que el carácter flexible, móvil, nomádico de la crónica permite aprehender de mejor manera. La mayoría de los habitantes urbanos se relacionan con la ciudad en el tránsito obligado, muchas veces vertiginoso, por algunos lugares. Pero ya no se merodea, ya no se deambula, el flaneur baudelairiano va desapareciendo, ahora sobre todo se fluye por "no lugares", por esas "instalaciones necesarias para la circulación acelerada de las personas y los bienes" (Marc, 1995, p. 41), pobladas de seres marginales, peligrosos, "anormales", que ya no permiten el encuentro y que se multiplican, como los de la marginalidad lemebeliana.

Aunque la violencia simbólica y material de la ciudad moderna, y el vértigo de su desproporción creciente, provoquen esos drásticos procesos de descentralización, desurbanización y desterritorialización, las crónicas de Lemebel nos permiten ver que, pese a ello, los homosexuales santiaguinos, en su condición de grupos subalternos, son también, y muy significativamente, una "tribu" (como diría Maffessoli, 1993) cultural, social, incluso políticamente viva. Es una marginalidad derivada de la preferencia sexual "anormal", de la pobreza y del fenotipo mapuche, que caracteriza a la mayoría de los protagonistas de estas crónicas, y que establece espacios de solidaridad donde, como veremos, la condición sexual no es óbice para la interacción social con la familia, los vecinos, incluso con los clientes de las "locas". Así, los lugares del habitar, del negocio y la diversión de los homosexuales se convierten en sus espacios sagrados, de la memoria, de las relaciones, de la vida; mientras esos mismos espacios son "no lugares" para los seres

7 Ahora, más que nunca, la calle es "ese caos móvil donde la muerte llega galopando por todos lados al mismo tiempo", como advirtió Baudelaire. 
"normales" que los evitan (aparentemente) o son apenas espacios fugaces por el vértigo de un tránsito obligado por la inevitable necesidad de atravesarlos hacia otros rumbos o de gozarlos prohibida, rápida y anónimamente.

Los desprocesos señalados tienen como una de sus consecuencias la constitución de diversas tribus que también son agentes de reterritorialización, en el sentido dado por Giménez (1996), de nuevas formas de usar y relacionarse con el espacio (el territorio es cualquier superficie habitada, pero valorizada instrumental y culturalmente), de construcción y fortalecimiento de geosímbolos; como el barrio de San Camilo, "un perdido reducto del travestismo prostibular que desaparecía en Santiago" (p. 39), un "no lugar” reterritorializado por el travestismo prostibular. Ahí, el geosímbolo resulta de la fusión de las solidaridades a las que convoca/n la/s marginalidad/es y de los imaginarios de la cultura de masas que se confunden con los de la popular: en San Camilo el espacio es marcado a lo Hollywood, con las manos en el cemento fresco, por "las travestís más bellas que nunca engalanadas para la première posando a la prensa alternativa, mostrando la silicona recién estrenada de sus pechos" (p. 40), en una mascarada teatral y corporal, cuya denominación, "Lo que el sida se llevó", transmutó la metáfora en realidad. Son solidaridades que crean cohesiones, comunidades en torno a identidades surgidas en la marginalidad.

Pero a diferencia de las megalópolis del Norte, en las ciudades latinoamericanas hay una heterogeneidad multitemporal donde el imaginario hollywoodense reviste cuerpos y mentalidades (v. gr., la Madonna, travesti espectacular que era una "copia mapuche" de su diva, la irreverente cantante anglosajona) y donde los elementos de la modernidad coexisten con tradiciones premodernas: "América Latina travestida de traspasos, reconquistas y parches culturales - que por superposición de injertos sepulta la luna morena de su identidad" (p. 127). Sin embargo, y pese a la modernidad yal glamour holywoodense, perdura la magia de la cultura popular tradicional:

[...] menos esa flaca cabello de ángel que hizo el teatro del desmayo en el cementerio, y sus quejidos de perra asmática partían el alma. Menos ella, que antes de sellar el cajón, como al descuido, le echó adentro cigarros y fósforos porque su amiga no podía dormir sin fumar (p. 83). 
Pese al vértigo centrífugo de la modernidad citadina, el barrio sigue actuando como una compleja red de solidaridades e interacciones vecinales que, incluso, trasciende las diferencias "anormales" de género. Más aún en barrios populares donde se expresa "la naturaleza social de los sentimientos" y donde "nos indignamos en común” (Durkheim), pues más importante que esas diferencias es la marginalidad mayor de la pobreza que identifica a los habitantes de las barriadas y remite — según Maffessoli (1993)_

\section{[...] a su misteriosa fuerza atractiva que hace que algo tome cuerpo. Es en este marco en el que se expresa la pasión y se elaboran las creencias comunes, o simplemente se busca la compañía de los que piensan y de los que sienten como nosotros (p. 39).}

Insistamos, más fuerte que esa "anormalidad” de los homosexuales, es la solidaridad vecinal en la pobreza y en la represión dictatorial. Esto es evidente en la cotidianidad barrial de la Regine: "Todo el barrio Mapocho conoce y ama la caminada de la Regine, cuando bolsa en mano culebrea entre los puestos de la Vega Central... Regine no te mueras nunca, tocando la fruta con su mano de caracol, riendo y chachareando con las mujeres de tetas infladas como melones" (p. 30). O en el símbolo en el que se convierte el entierro de la Chumilou que coincidió con el día en que llegó la democracia y con los festejos de "cientos de jóvenes descamisados que se encaramaron en la carroza, brincando sobre el techo, colgándose de las ventanas, sacando pintura spray y rayando todo el vehículo con graffitis que decían: Adiós tirano, Hasta nunca pinocho, Muerte al chacal” (p. 25), suerte de alegórico agradecimiento a la generosidad de la Chumi: "para las colas travestis, les dejo la mansión de cincuenta habitaciones que me dio el sheik, para que hagan una casa de reposo para las más viejas" (p. 23).

Lo propio en el entierro de la Regine "que recibió todos los homenajes del barrio La Vega el día plateado de su funeral. Esa tarde se despoblaron los puestos y una nevada de pétalos cayó desde el cuarto piso cuando los cargadores bajaron el ataúd” (p. 36). O la solidaridad clandestina en el sexo y la política (por un sentimiento subversivo común) entre la Regine y Sergio, el único conscripto que se salva del ano mortal de esta loca que inoculó de sida a los milicos de la dictadura mientras lo penetraban los 
locos afanes sexuales de esos "machos" sodomitas. O la solidaridad de la tribu con la Madonna cuando el sida desmantelaba su cabellera oxigenada, "la hermosa peluca platinada que le regalamos para la Pascua, que nos costó tan cara, que todos los travestis le compramos en el centro juntando las chauchas, peso a peso durante meses" (p. 37). O con Loba Lamar, "un rescoldo pisoteado del África travesti”" (p. 46), a quien las locas que compartían con ella un miserable cuarto y las miserias de la prostitución sodomita, se turnaban "para cuidarla, para lavarle el poto como una guagua" cuando ingresó en la delirante y larga agonía sidosa y les provocó un desvelo de días y las ganas incontenibles de "apretarle el cogote" para terminar de una vez el calvario compartido. Pero más pudo la solidaridad para aplacar en algo los rigores de esa agonía que anunciaba la de cada una de ellas y reclamaba reciprocidad cuando el manto invernal del sida les llegase.

Pero la marginalidad no implica una subordinación pasiva. En los microespacios de las tribus se producen "microrresistencias que fundan microlibertades" (De Certeau, 1996), que expresan utopías, que buscan subvertir el orden, el de la cotidianidad y el otro, el de una sociedad excluyente y el de la brutal dictadura. Así, la doble marginalidad exige una doble liberación. Por un lado, la lucha permanente por reivindicar sus espacios e identidad sexual, incluso en la muerte: "solamente quiero que me entierren vestida de mujer — pide la Chumilou agonizante—; con mi vestido de trabajo, con los zuecos plateados y la peluca negra. Con el vestido de raso rojo que me trajo tan buena suerte" (p. 23). Por otro, y fundamentalmente, está la rebeldía ante la dictadura, pues, a diferencia del patrón gay del Norte, "otro corpus tribal diferenciaba sus ritos. Otros delirios enriquecían barrocamente el discurso de las homosexualidades latinoamericanas. Todavía la maricada chilena tejía futuro, soñaba despierta con su emancipación junto con otras causas sociales" (p. 26). Una metáfora muy significativa al respecto es el uso del sida como arma por parte de la Regine y sus locas del piso cuarto de Aluminios el Mono, quienes ano en ristre matan a plazos a los elementos del ejército represor de Pinocho el Chacal, excepto al Sergio, que es el único consciente de la brutalidad dictatorial y que se salva de las municiones de efecto retardado, por el amor y coincidencia política con la reina del serrallo sodomita. 


\section{O en la Madonna quien}

[...] nunca le tuvo miedo a los pacos. Se les paraba bien altanera la loca, les gritaba que era una artista, y no una asesina como ellos. Entonces le daban duro, la apaleaban hasta dejarla tirada en la vereda y la loca no se callaba, seguía gritándoles hasta que desaparecía el furgón (p. 38).

O en la representación carnavalesca y subvertora de las Yeguas del Apocalipsis, en el barrio de San Camilo, que logró convocar (otra muestra de solidaridad más allá de las inclinaciones sexuales) a "toda la resistencia cultural en dictadura, políticos, artistas, teóricos del arte, fotógrafos y camarógrafos sapeando la performance" (p. 40).

Pero, de todas formas, las crónicas de Lemebel dejan ver una ciudad hostil, la que es el producto de una sociedad injusta, donde se "taconea el laburo filudo del alma ramera" para llevar unos pesos al hogar miserable y paliar las necesidades básicas, esas mismas que quebraron las precauciones de la Chumilou aquella noche en que no le quedaba un solo condón " $y$ el gringo impaciente, urgido por montarla, ofreciendo el abanico verde de sus dólares. Entonces, la Chumi cerró los ojos y estirando la mano agarró el fajo de billetes... y sacó pasaje de ida en la siniestra barca” (p. 23). Es la misma injusticia que obliga a la casi totalidad de los homosexuales de estas crónicas a vender su cuerpo marginal, apócrifo, subalterno; y a buscar con ansia el amor porque "Usted no sabe / Cómo cuesta encontrar el amor / En estas condiciones / Usted no sabe / Qué es cargar con esta lepra / La gente guarda las distancias" (p. 95). Pero también esa hostilidad es explícita:

[...] nunca se sabe si mañana en algún rincón de Santiago su aleteo trashumante va a terminar en un charco. Nunca se sabe si una bala perdida 0 un estampido policial le va a cortar el resuello de la cigüeña moribunda. Acaso esta misma madrugada de viernes, cuando hay tanta clientela, cuando los niños del barrio alto se entretienen tirándoles botellas desde los autos en marcha (p. 86).

Es una ciudad hostil que recuerda el Focilá (Folclore de Ciudad Latino, otra forma de la crónica latinoamericana) de Rubén Blades y su 
drama de la noche prostibular (Pedro Navaja, Juanito Alimaña... ); una ciudad donde la necesidad carnal y estomacal entran inexplicablemente en duelo y cobran su víctima, como con Willy Oddo (uno de los Quilapayún) y el pequeño pero certero cortaplumas del travesti de 17 años que pagó doble, con el sida y la cárcel (que para los homosexuales es casi la misma muerte lenta y terrible), por "degollar un gorrión con la caricia de un filo" (p. 116), pues "el Willy nunca imaginó que ese sábado la ciudad llevaba un aguijón en el escote" (p. 113). Y es que así como la ciudad es hija de la modernidad, la reivindicación de la noche lo es de la ciudad moderna. La electricidad tuvo la magia de alargar el día refuncionalizando la noche que antes marcaba y delimitaba los ritmos y las actividades del mundo premoderno. Ahora, la noche es el ámbito perfecto del submundo citadino y del travestismo seductor, es el espacio de la liberalidad total de las tribus y de la explosión de los "no lugares" de las locas (y otros cuerpos subalternos) y sus múltiples dramas:

Como un milagro de media noche, el travestismo callejero es un brillo cocheperla que relumbra en el zaguán del prostíbulo urbano. Apenas un pestañazo, un guiño colifrunci, un desnudo de siliconas al aire, al rojo vivo de los semáforos que sangran la esquina donde se taconea el laburo filudo del alma ramera (p. 77).

\section{Las sobrecargas representativas}

Martín-Barbero (2002) habla de las sobrecargas representativas; es decir, de los

[...] modos vistosos de la decoración urbana y del vestir, retóricas del lenguaje político, dramáticas televisivas, narrativas radiales del deporte, en lo que tienen de afirmación del Tercer Mundo y a la vez de simulacro trabajado por la modernización/imitación del primero (p. 10).

En este sentido, la escritura de Lemebel es una suerte de barroco popular que corresponde al recargado y polisémico referente al que alude: la espectacularidad, la retórica del exceso, el derroche, la exageración, el 
gesto recargado, el doble sentido, las "malas palabras", un escandaloso estilo en el vestir con colores y formas explosivas, etc., que contradicen la norma burguesa y lo que la imposición simbólica hegemónica considera legítimo.

Bastante significativo al respecto, más allá de la comicidad del hecho tan brillantemente recreado por Lemebel, ${ }^{9}$ es esa apropiación de los espacios sagrados de la cultura citadina que las locas logran, por una serie de hechos azarosos, al difundir el video del streaptease de la Madonna en un acto de la "alta cultura" realizado en el Museo Nacional de Bellas Artes de Santiago. No solo que en la Madonna se da una identidad de género (que también expresa la solidaridad señalada, más allá de la "anormalidad" sexual) al escoger para la producción de su video a una mujer (Gloria Camiragua), sino que es una bofetada pública a una sociedad pudibunda, cuya doblez es potenciada por su pacatería. Bofetada más fuerte aun porque uno de los públicos que gozan con el cuerpo desnudo de este travesti transculturado y desacralizador "tal como Dios la echó al mundo, pero ocultando la vergüenza del miembro entre las nalgas. El candado chino del mundo travesti que simula una vagina echándose el racimo para atrás" (p. 40), son escolares que aplauden a rabiar cuando "el elástico se suelta y una falo porfiado desborda la pantalla. Casi le pega en la nariz al jefe de brigada" (p. 42). Este acto transgresor le costaría el puesto al director del Museo, Nemesio Antúnez, por haber permitido esa "pura mugre libertina que desprestigiaba la democracia", y significaría la expulsión de otros artistas.

Pero es en la exageración, en los "modos vistosos del vestir", donde se expresa mejor esa sobrecarga representativa. Está en el "duplicado mapuche casi perfecto" de la Madonna que "cuando se puso la silicona le dio por los escotes, los clientes se volvían locos cuando ella les ponía las tetas en la ventana del auto. Y parece que veían a la verdadera Madonna diciendo: Míster, lovmi plis” (p. 38). Está en las pelucas, en las pieles, en las minifaldas, en el maquillaje de un barroco luminoso. Está en los entierros de las locas que se convierten en una suerte de carnaval grotesco (en el sentido de la fiesta subversiva popular de Bajtin) que exorciza la "som-

\footnotetext{
8 Recuérdese a Octavio Paz: “Son las malas palabras, único lenguaje vivo en un mundo de vocablos anémicos”.

9 La crónica titulada "La muerte de Madonna” (pp. 37-45).
} 
bra" de la sidosa muerte lenta y del estigma social que es otra forma de morir: en la década de 1990,

[...] los funerales de una loca contagiada por el sida se han transformado en un evento social. Una exhibición de modelos Calvin AIDS, recién estrenados, primorosamente escogidos, para despedir a la amiga como se lo merece, como nunca se soñó en el dorado aeropuerto del "nunca jamás" [...] las locas engalanadas con el drama han hecho de su muerte un tablao flamenco, una pasarela de la moda que se burla del sórdido ritual funerario. Más bien, revierte en la compasión que pesa como un juicio pecaminoso sobre el sida homosexual, lo transforman en alegoría... Lo relucen con la ópera comediante de su llanto (pp. 81, 82).

Pero que no llame a engaño, la mascarada no es solo de la "maricueca", tras la máscara del arquetipo viril homófobo se esconde la realidad de la doble moral hegemónica:

[...] la atracción de esta mascarada ambulante [siliconas, escotes explosivos, minis deslumbrantes...] nunca es tan inocente, porque la mayoría de los hombres, seducidos por este juego, siempre saben, siempre sospechan que esa bomba plateada nunca es tan mujer... Algo la desborda en su ronca risa loca (p. 84).

Así, los "no lugares" de la "normalidad" se convierten en espacios sagrados, fugaces pero recurrentes, para los seres "normales" y "donde la transexualidad es otra ley de tránsito que desvía el rutinario destino del marido camino al hogar" (p. 85).

\section{Conclusión: el subalterno, la biopolítica y la geopolítica de conocimiento}

Pero que den paso a los que hacen los mundos y los sueños, las ilusiones, las sinfonías, las palabras que nos desbaratan y nos construyen, los más locos que sus madres, los más borrachos que sus padres y más delincuentes que sus hijos $y$ más devorados por amores calcinantes. Que les dejen su sitio en el infierno, y basta.

Roberto Fernández Retamar 
$\mathrm{Al}$ inicio señalábamos que hay una biopolítica que busca controlar, disciplinar; y una geopolítica del conocimiento que construye y establece una subalternización geocultural, política, racial..., pues legitima y valida lo que el poder impone como lo normal y correcto, mientras castiga y menosprecia lo contrario, como es el caso del colectivo que representa Lemebel. En este sentido, la visibilización y reivindicación de estos "otros" comportamientos y conocimientos - como formas alternativas y distintas de actuar y concebir, producir y utilizar saberes-, que se dan en la obra del cronista chileno, tienen el carácter subversivo y antidisciplinario de descolonizar el conocimiento, deconstruir los regímenes de verdad y minar esas geopolíticas hegemónicas cognoscitivas, esas que impiden ver que el pensamiento tiene otras fuentes con lógicas diferentes, pero también válidas y validadas por ciertas prácticas sociales; por tanto, legítimas. Todo esto viene a cuento a propósito de una de las múltiples lecturas que suscitan las crónicas de Lemebel.

Entre otras cosas, la sociedad contemporánea es profundamente patriarcal, pues asigna papeles sexuales diferenciados a lo masculino (activo y dominante) y a lo femenino (pasivo y dominado). Es una sociedad falocrática que ve como detestable aquello que atenta contra el orden de la reproducción sexual y los papeles y rituales que constituyen el canon y la norma hegemónica. En este sentido, el homosexual es visto como una amenaza social por quebrar el orden patriarcal, por transgredir la función procreativa y los papeles sexuales, por hacer una farsa de las normas morales de la sociedad patriarcal $y$ atentar contra la imagen del ciudadano ideal. $\mathrm{Al}$ recrear artísticamente a ese colectivo marginal y amenazante, Lemebel reivindica su mundo, sus saberes, sus cuerpos, su cultura para universalizarlos, darles/ exigir legitimidad y para convocarlos a una práctica política más orgánica, a una práctica "politizante para maricomprenderse" (p. 124) y luchar contra la biopolítica y la colonialidad del poder.

Revelación y rebelión en Lemebel contra la categorización de ilegítimo, anormal, inmoral, enfermo y perverso desde una concepción hegemónica de masculinidad que estigmatiza los modos de sentir, pensar y actuar que desestabilizan las normas y rituales logo-falo-céntricos de la 
sociedad como fundamento de la "modernidad biológica", de un "biopoder"; pues su narrativa, así como su vida y la de sus congéneres representados (en el doble sentido señalado), está

[...] contra un sistema logocéntrico que ha negado el placer de lo anal, para restringirlo a la exclusiva función de la excreción, Lemebel elabora una "poética del esfínter" que desestabiliza y descentraliza desde los bordes devaluados del acto sexual homoerótico [...] El falo como signo y emblema del Orden Simbólico patriarcal se exilia en la Ley del Padre para penetrar en el receptáculo fecal que no germinará en ningún "vientre bendito". Semen y excremento, ardor de esfínter y sangre no menstrual configuran así lo abyecto, en su sentido de aquello que perturba el lenguaje de la identidad y el orden (Guerra, 2000, pp. 89-90).

En definitiva, contra esa colonialidad de poder que produce una geopolítica de conocimiento y pretende imponer como inmutable y legítimo un modelo de sociedad falocéntrico y patriarcal, se rebela el acto escritural y existencial de Lemebel a fin de reivindicar y exigir un estatuto legítimo para el mundo "otro" de la homosexualidad. Y todo ello desde su condición de subalterno.

En este sentido, cabe preguntarse ¿puede hablar el subalterno? La pregunta que se formula Spivak (citado en Beverley, 1999) es muy pertinente en Lemebel, quien, sin duda, es un subalterno dado que lo que define la subalternidad es la negación y la exclusión; es decir, la marginalidad. Ranajit Guha señala que el subalterno es "a name for the general attribute of subordination [...] Whether this is expressed in terms of class, caste, age, gender, and office or in any other way" (citado en Beverley, 1999, p. 26). Por lo tanto, Lemebel lo es por partida triple, por "maricón, pobre e indio"; con el agravante de que por ser una "loca tercermundista”, la diferencia con sus correligionarios anglosajones está marcada más profundamente. ${ }^{10}$

10 Cuando visitó, por invitación con todos los gastos pagados, el bar Stonewall en el Village de Nueva York, "el santuario de la causa homosexual”, fue evidente el sentimiento de exclusión que sintió y que le hicieron sentir los cofrades de ese Olimpo blanco de "homosexuales potentes y bien comidos que te miran con asco, como diciéndote: $\mathrm{Te}$ hacemos el favor de traerte, indiecita, a la catedral del orgullo gay” (pp. 70,71). 
Pero la pregunta de Spivak parte de una premisa equivocada: la supuesta mudez del subalterno. Ya en el concepto de la 'literatura iletrada' de Zapata Olivella (1997) se plantea como sustrato o yacimiento fundamental del hecho literario a diversas manifestaciones, sobre todo orales, de las culturas subalternas que viven y caminan vigorosamente al margen de los cenáculos letrados y académicos: poemas, gestas, canciones, fiestas, ritos y mitos. Es decir, el subalterno siempre ha hablado, aunque frecuentemente haya sido marginado de las vías y artefactos legitimados, ${ }^{11}$ en especial los medios de comunicación.

Posiblemente, Spivak se refiere a estos modos y vías de hablar legitimados por la cultura letrada. En este sentido, también es pertinente lo de Lemebel: no solo que puede, sino que lo hace y muy bien, tanto que su obra ha sido reeditada, más allá de su Editorial Cuarto Propio, por editoriales como Anagrama y Seix Barral; ha obtenido reconocimiento internacional que se ha traducido en el otorgamiento de becas (Guggenheim y Fundart), premios como el José Donoso (2013) y el Premio Nacional de Literatura (2014), en invitaciones a importantes actos en México, Cuba, los Estados Unidos. Su obra es estudiada en la academia metropolitana; además de haberle garantizado un empleo permanente como columnista en algunos medios impresos (sobre todo en Punto Final y en The Clinic). Es decir, su subalternidad como pobre e iletrado (o letrado sin reconocimiento) pasó a la historia. Pero ¿realmente dejó de ser un subalterno? Sin duda que el nivel económico que alcanzó le permitió superar esa condición que en algún momento lo obligó a prostituir su cuerpo homosexual (al menos, eso se colige de sus crónicas marcadamente autobiográficas). Sin embargo, en su condición de letrado transgénero y "mapuche”, ¿lo logró? La experiencia en Stonewall parece decirnos que no; a la final, pese a lo que haga, nunca será un Truman Capote o un Andy Warhol o un Rock Hudson para la sociedad anglosajona; ni siquiera para la misma sociedad chilena, empezando por su izquierda: "Mi hombría no la recibí del partido / Porque me

11 Recuérdese que, en su propuesta de "transculturación desde arriba", Rama habla de que las obras literarias "coronan" las culturas. Sin quitar la importancia que estos artefactos culturales tienen (si no destacásemos su importancia, no estaríamos analizando estos textos letrados), es indudable que hay expresiones populares significativas a través de las cuales el subalterno "habla" desde el margen y, muchas veces, sin salir de él. 
rechazaron con risitas / Muchas veces I [...] I Tengo cicatrices de risas en la espalda" (pp. 95, 96).

Por otra parte, en cuanto subalterno, ¿habla para el subalterno, para aquel más cercano a la estética de los medios de comunicación que a la del libro? Sin duda que no. Pese a la prosapia popular y la riqueza poética de su prosa, de su "literatura iletrada", y pese al "loco afán" reivindicativo que la impulsa, con frecuencia resulta difícil su lectura. La mayoría de las citas en este trabajo ilustran lo dicho. Y es que, dada su perspectiva ideológica y su proyecto reivindicativo, los marginales no son el público al que quiere llegar. $\mathrm{Al}$ igual que Garcilaso de la Vega o José María Arguedas (que optaron por la norma lingüística dominante para lograr una comunicabilidad eficiente de sus demandas - pero con la diferencia de que el cronista chileno es a la vez protagonista de las historias narradas-), Lemebel hace uso de un discurso "oficial" auratizado, se apropia de un lugar para autolegitimarse, para procurarse, como lo ha señalado Dino Plaza (1999),

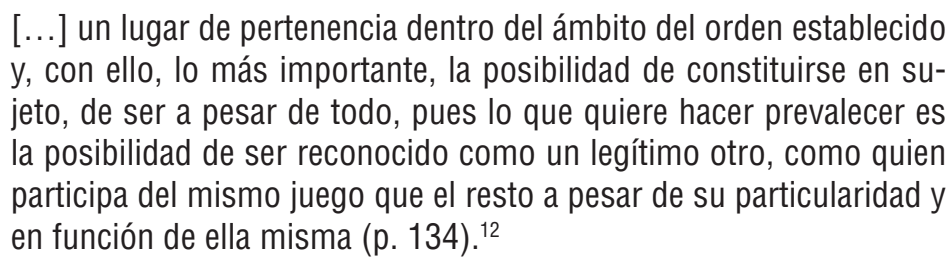

Frente a diversas posibilidades diglósicas (Lienhard, 1996), este (¿ex?) subalterno optó por la que más le convenía a sus propósitos. Es una escritura contra el olvido y en favor del corazón, de la memoria; dada por la necesidad imperiosa de dejar su marca, de contar su historia (que es la de muchos), de interpelar y denunciar, de exorcizar el trauma de la múltiple marginalidad homosexual, a través de la crónica que en sí misma ya es desacralizadora y muy política (pues cuenta "las historias que nos enseñaron a no considerar noticia”, Caparrós, 2007, p. 9). Posiblemente Lemebel no buscó esa autolegitimación, ese lugar, ese reconocimiento. Lo que

12 Coincidimos con Plaza, excepto en esto de "constituirse como sujeto" detrás de lo cual está la ya criticada idea de que solo a través de expresiones o artefactos culturales "oficiales" y legitimados por la imposición hegemónica (la cultura letrada, por ejemplo) el individuo puede constituirse como sujeto. 
sí es claro es ese "loco afán” por revelar y rebelarse. Con este fundamental propósito tuvo que aprender y utilizar "la lengua patriarcal para maldecirla” (p. 124).

\section{Referencias}

Arboleda Ríos, P. (2011). ¿Ser o estar “queer” en Latinoamérica? El devenir emancipador en Lemebel, Perlongher y Arenas. Íconos: Revista de Ciencias Sociales, 39, 111-122.

Augé, M. (1995). Los "no lugares": espacios del anonimato: una antropología de la modernidad. Barcelona: Gedisa.

Beverley, J. (1999). Subalternity and representation: Arguments in cultural theory. Durham: Duke University Press.

Blanco, F. y Poblete, J. (2010) (eds.). Desdén al infortunio. Sujeto, comunicación y público en la narrativa de Pedro Lemebel. Santiago de Chile: Cuarto Propio.

Caparrós, M. (2007). Por la crónica. En Actas del IV Congreso Internacional de la Lengua Española. Cartagena, Colombia.

Caparrós, M. (2009). Una luna. Barcelona: Anagrama.

Caparrós, M. (2015). Hambre. Barcelona: Anagrama.

Carrión, J. (ed.) (2012). Mejor que ficción. Crónicas ejemplares. Barcelona: Anagrama.

Certeau, M. de (1996). La invención de lo cotidiano. México: Universidad Iberoamericana.

Checa Montúfar, F. (2003). El Extra: las marcas de la infamia. Quito: Abya Yala. 
Checa Montúfar, F. (2014). Crónica y [semi]modernidad en América Latina. En C. Yánez (ed.), Premio CIESPAL de Crónica (pp. 15-69). Quito: Quipus.

Fondo de Cultura Económica (2006). Lo mejor del periodismo de América Latina. México: FCE, FNPI.

Fonseca, D. y El Khadi, A. (eds.) (2012). Sam no es mi tío. Veinticuatro crónicas migrantes y el sueño americano. Barcelona: Alfaguara.

Foucault, M. (1994). Vigilar y castigar. Madrid: Siglo XXI.

Giménez, G. (1996). Territorio y cultura. Estudios sobre las Culturas Contemporáneas, 2(4), 9-30.

Goffman, E. (1981). La presentación de la persona en la vida cotidiana. Buenos Aires: Amorrortu.

González, A. (1983). La crónica modernista hispanoamericana. Madrid: Porrúa.

González Cangas, Y. (2007). Etnografía persistente: Pedro Lemebel o el poder cognitivo de la metáfora. Atenea, 496, 161-165.

Guerra Cunningham, L. (2000). Ciudad neoliberal y los devenires de la homosexualidad en las crónicas urbanas de Pedro Lemebel. Revista Chilena de Literatura, 56, 71-92.

Jaramillo, D. (2012) (ed.). Antología de crónica latinoamericana actual. México: Alfaguara.

Lemebel, P. (2000). Loco afán. Barcelona: Anagrama.

Lienhard, M. (1996). De mestizajes, heterogeneidades, hibridismos y otras quimeras. En Asedios a la heterogeneidad cultural (pp. 56-80). Philadelphia: Asociación Internacional de Peruanistas. 
López Morales, B. (2011). La construcción de "la loca" en dos novelas chilenas: El lugar sin límites de José Donoso y Tengo miedo torero de Pedro Lemebel. Acta Literaria, 42, 79-102.

Maffesoli, M. (1993). El tiempo de las tribus: el declive del individualismo en las sociedades contemporáneas. Madrid: Icaria.

Marconi, A. E. (2012, mayo). Concepción de ciudadanía en el Manifiesto de Lemebel. En VIII Congreso Internacional Orbis Tertius de Teoría y Crítica Literaria. Recuperado el 23 de enero de 2015 de http:// sedici.unlp.edu.ar/handle/10915/30041

Maristany,J.J. (2008). ¿Una teoría queer latinoamericana? Posestructuralismo y políticas de la identidad en Lemebel. Lectures du genre, 4, 17-25. Recuperado el 23 de enero de 2015 de http://www.lecturesdugenre.fr/Lectures_du_genre_4/Maristany_files/MARISTANY.pdf

Martín-Barbero, J. (1992). Introducción. En J. Martín-Barbero y S. Muñoz (coord.), Televisión y melodrama. Bogotá: Tercer Mundo.

Martín-Barbero, J. (2002). Oficio de cartógrafo: travesías latinoamericanas de la comunicación en la cultura. México: Fondo de Cultura Económica.

Mignolo, W. (2003). La colonialidad a lo largo y ancho: el hemisferio occidental en el horizonte colonial de la modernidad. En E. Lander (comp.), La colonialidad del saber: eurocentrismo y ciencias sociales: perspectivas latinoamericanas. Buenos Aires: Consejo Latinoamericano de Ciencias Sociales (Clacso).

Monsiváis, C. (2001). El amargo, relamido y brillante frenesí. En P. Lemebel, La esquina es mi corazón. Santiago de Chile: Seix Barral.

Morales, L. (2009). Pedro Lemebel: género y sociedad. Aisthesis, 46, 222-235.

Moure, C. I. (2014). La voz de los cuerpos que callan (Tesis de doctorado, Universidad Nacional de La Plata, Facultad de Humanidades y 
Ciencias de la Educación). Recuperado el 23 de enero de 2015 de http://www.memoria.fahce.unlp.edu.ar/tesis/te.1001/te.1001.pdf

Osorno, G. (comp.) (2009). Crónicas de otro planeta. Las mejores historias de Gatopardo. México: Debate-Random House.

Paz, O. (1998). El laberinto de la soledad. México: FCE.

Plaza, D. (1999). Lemebel o el salto de doble filo. Revista Chilena de Literatura, 54, 123-135.

Poblete Alday, P. (2014). Las narrativas del Yo en la crónica contemporánea. Anales de Literatura Hispanoamericana, 43, 241-254.

Ramos, J. (1989). Desencuentros de la modernidad en América Latina. Literatura y política en el siglo XIX. México: Fondo de Cultura Económica.

Rebollo, E. (2014, 1 de febrero). Jon Lee Anderson compara la crónica latinoamericana con el "boom" literario. Recuperado el 23 de enero de 2015 de http://noticias.lainformacion.com/politica/libertadde-prensa/jon-lee-anderson-compara-la-cronica-latinoamericanacon-el-boom-literario_S166BaSyiml7JO9ieEQ026/

Reguillo, R. (2000). Textos fronterizos. Diá-logos de la Comunicación, $58,61-62$.

Richard, N. (1994). Masculino/femenino. Prácticas de la diferencia y cultura democrática. Hispamérica, 23(67), 121-123.

Rotker, S. (1992). La invención de la crónica. Buenos Aires: Letra Buena.

Rossi, A. (2013). Construcción de lazo social en "La noche de los visones" y "La Regine de Aluminios el Mono" de Pedro Lemebel. Catedral Tomada. Revista de crítica literaria latinoamericana, 1(2), 60-68. Recuperado el 27 de enero de 2015 de http://dx.doi.org/10.5195/ct/2013.46 
Sabo, M. J. (2014). Un camp desde el margen: el cuerpo mestizo de Latinoamérica en la crónica de Pedro Lemebel. RECIAL: Revista del CIFFyH Área Letras, 5(5-6). Recuperado el 27 de enero de 2015 de http://revistas.unc.edu.ar/index.php/recial/article/ view/9612/10377

Silva, M. y Molano, R. (eds.) (2006). Las mejores crónicas de Gatopardo. Bogotá: Debate.

Villanueva Chang, J. (2012). El que enciende la luz. ¿Qué significa escribir una crónica hoy? En D. Jaramillo Agudelo (ed.), Antología de crónica latinoamericana actual (pp. 583-606). Barcelona: Alfaguara.

Villoro, J. (2012). La crónica, ornitorrinco de la prosa. En D. Jaramillo Agudelo (ed.), Antología de crónica latinoamericana actual (pp. 577582). Barcelona: Alfaguara.

Yánez, C. I. (ed.) (2014). Premio CIESPAL de Crónica 2014. Quito: Ciespal.

Zapata Olivella, M. (1997). La rebelión de los genes. El mestizaje americano en la sociedad futura. Bogotá: Altamir. 